\title{
JURAL RELATIONS AND THEIR CLASSIFICATION
}

\author{
Arthur L. Corbin \\ Professor of Law, Yale University, School of Law
}

In a number of articles published in several law magazines ${ }^{1}$ Professor Albert Kocourek has taken occasion to consider and to criticise the work of the late Wesley $\mathrm{N}$. Hohfeld with respect to our fundamental legal conceptions. He has generously given credit to Hohfeld's genius and constructive service, and has done him the signal honor of building upon his foundation, even though he undertakes extensive repairs and. alterations.

To one who worked side by side with Hohfeld, discussed matters with him daily, and approved of most of his results, it would be a pleasure to consider Professor Kocourek's reconstruction in detail, and by the use of parallel columns and footnotes to obliterate the repairs and undo the alterations. This would necessitate the reprinting of a great part of his article, and it is not at all feasible. It seems more desirable to go straight to the corner-stone of the whole structure, and to present in independent fashion a theory of jural relations and of law, a theory that the writer believes to have underlain Hohfeld's classification and to be the one that also underlies our current judicial reasoning and terminology.

In determining what is the law in any given case, we are invariably interested in finding the answer to one question: what will our organized society, acting through its appointed agents, do? It is often necessary for us to know what the forces of nature will do and what individuals who do not represent organized society will do. Will the wind blow down my house? Will the rain spoil my hay? Will the engineer fall asleep? Will thieves break through and steal? Our prosperity and even our survival depend upon our answers to these questions, but when we study them we are not studying law. But suppose $I$ ask: If $A$ borrows money of $B$ and fails to repay, will the court give judgment and the sheriff levy execution? If $A$ attacks $B$, and $B$ knocks $A$ down with reasonable violence, will the court give judgment against either one and the sheriff enforce the judgment? If $A$ enfeoffs $B$ of Blackacre and $C$ thereafter breaks the close will the court award damages to $B$ ? Our prosperity and our survival depend upon our ability to answer these questions also. They deal with the conduct of societal agents, and when we study them we are studying law.

\footnotetext{
'The Hohfeld System (I920) I5 ILL. L. REv. 24; Various Definitions of Jural Relation (1920) 20 Col. L. Rev. 394; Rights in Rem (I920) 68 PA. L. Rev. 322; Plurality of Advantage and Disadvantage in Jural Relations (I920) ig MICH. L. REV. 47; Tabulae Minores Jurisprudentiae, supra, p. 215.
}

[226] 
The first set of questions we call 'questions of fact', and the answers to them are answers of fact. The second set of questions we call 'questions of law', and the answers require us to know and to apply a rule of law. In each case this is equally true whether the answer is negative or affirmative. The wind will blow, or it will not blow; the air will move, or it will stay still. The court will give judgment for $A$, or it will give judgment for $B$. The sheriff will levy execution, or he will not levy execution.

In dealing with law, therefore, we are considering the conduct of societal agents and the rules expressing that uniformity with which they are expected to act. These rules are rules of law; but the rules that enable us to predict merely the action of natural forces or of individuals who are not societal agents are not rules of law. There is no supernatural or mystical distinction between physical relations and legal relations. Rules of physics and rules of law are alike in that they enable us to predict physical consequences and to regulate our actions accordingly. When the physical event that we are predicting is the conduct of a state agent, executive or judicial, acting for society, the rule that we are applying is called a rule of law; and with respect to the expected action of societal agents, our relations to our fellow men are commonly called legal (or jural) relations. ${ }^{2}$

It is not meant by the foregoing that this is the only possible usage of the terms in question. It is believed to be the actual usage, and that it is of advantage to abide by it. According to this usage, there is no law and there can be no legal relations of any sort where there is no organized society. The fact that is essential is the existence of societal force; and the question that is of supreme interest is as to when and how that force will be applied. What will the community of

\footnotetext{
2 It is pleasant to observe Professor Kocourek's recognition of the fact that a jural relation is always that of one individual person to another. (1920) I5 ILL. L. REv. 26. This fact has a very far-reaching effect upon much juristic thought and expression. It sends to the scrap heap a deal of juristic nonsense about corporate "entities" and rights of "the state" and "social interests" and other cherished fictions--cherished among ourselves as well as among our quondam friends in Prussia. It helps us to realize that acts are always individual; that pain and pleasure, emotions and desires, are always individual; that rules of law are made for individuals; and that human and social welfare is, in the last analysis, always individual welfare. Labor is not in conflict with capital; but a laborer with no capital may fight a laborer with capital. "Interests of personality" do not conflict with "interests of property," because only persons have interests, either factual or jural. One man's desire to hoard may conflict with another man's desire to eat, and the bystanders will determine the controversy in accordance with what appear to. be their personal interests; but we are dealing throughout with the interests of persons and not with the interests of things or of abstractions. A state, a corporation, a group, a union, can act and can be affected only through individuals. Societal evolution can take place only by the evolution of individuals. Socialism is always some form of individualism, some combination of individual relations.
} 
citizens cause their agents to do. It is this multitude of busy little fellow citizens who constitute "society" or "the state," and it is their cumulative strength that constitutes the personified giant whose arm may be so powerful to aid or to destroy. In law, the ultimate question is, what will this giant do?

Now with respect to the little individual, who will be called $A$, in whose fortunes we may be interested, this giant either will or he will not act; there is no third possibility (although a wide variety is possible in the kind of act that he may do). And the little individual, A, himself either can or he cannot do something that will stimulate the giant to act or not to act. The giant sleeps; can I wake him? He wakens; can I soothe him to inaction? From this it appears that we have four interesting possibilities: The giant will act so as to affect $A$, or he will not so act; A can influence the giant's conduct, or he cannot influence his conduct. Introduce a second little individual, $\mathrm{B}$, and you at once double these interesting possibilities. The giant will act for $A$ as against $B$, or he will not; he will act for $B$ as against $A$, or he will not. A can influence the giant's action with respect to $B$, or he cannot; $B$ can influence the giant's action with respect to $A$, or he cannot. Of course we are deeply interested in the particular sort of act the giant will do, and in the various ways in which $A$ and $B$ are able to affect the giant's conduct. So deeply are we interested in them that we have used them as a basis for classifying our huge legal mass into property and contract, crime and tort, equity and admiralty and common law and law merchant, substantive law and adjective law. All these classes cross and re-cross and overlap each other; but underneath them all we have eight fundamental conceptions with respect to any two little individuals, $A$ and $B$. The giant will aid $A$ against $B$, or he will not; he will aid $B$ against $A$, or he will not. A can stimulate the giant's conduct with respect to himself and $B$, or he cannot; $B$ can so stimulate the giant's conduct, or he cannot.

Now suppose that instead of continuing to repeat these rather lengthy and cumbrous sentences, we compress the eight ideas into eight single words. But never fail to remember that behind the single word is the same mental concept that is behind the longer and more cumbrous sentence. What eight single words shall we choose? By all means follow established usage if there is any. As usage is not in fact uniform, follow the usage that is the more common so far as that can be done, and yet avoid duplication and doubt. After a careful consideration of the prevailing legal verbiage, Hohfeld made a choice on the foregoing principles. He chose words already used in judicial reasoning and he allowed them to keep one of their customary meanings. Since they had several customary meanings, he tried in the interest of clearness and certainty of expression to slay all the extra meanings and to force us to adopt invariably the single meaning that he thought the most useful. His method of doing this was not by formal definition, 
but by arranging his terms in a table of correlatives and a table of opposites or negatives. ${ }^{3}$

What are these terms, and which fundamental concept does each one express? You will recognize them. The concept that the giant will aid A by forcibly controlling B's conduct we express by saying that $A$ has a RIGHT. If the giant will not so aid $A$, he has No RIGHT. If the giant will aid $B$ by using force to control A's conduct, $A$ has a DUTY. If he will not so aid $B$, and $A$ is free from such constraint, this fact is expressed by saying that $A$ has a PRIvILEGE. If $A$ can, by his voluntary act, influence the giant's conduct with respect to $B$, whether to act or not to act, and whether presently or contingently, $A$ has a POWER. If $\mathrm{A}$ cannot do this, he has a DISABILITY. If $\mathrm{B}$ can, by his voluntary act, influence the giant's conduct with respect to $A, A$ has a LIABILITY. If $B$ cannot do this, $A$ has an IMMUNITy.

Here we have Hohfeld's table of eight terms, expressing certain conceptions that he believed to be fundamental. They are fundamental because they are the conceptions out of which in various combinations we construct our conceptions of property, ownership, trust, easement, license, right of entry, patent, franchise, chose in action, contract, debt, quasi-contract, and other important complexities. They are fundamental because they are constant elements, into which all of our variable combinations can be analyzed, common denominators to which the superficially dissimilar, like law and equity, property and contract, can be reduced. One may well have not the slightest interest in them except so far as they are useful in actual life and make the administration of justice more easy and certain. But it is a great service if they enable us to see similarities and distinctions otherwise concealed and help us toward a consistent legal sytem. To adopt and use them does not mean that we must abandon our former language and our former

"Professor Kocourek has difficulty with Hohfeld's term "opposites". As to this it is unnecessary to take issue with him. To us "opposites" has meant the same as his "contradictories". For this reason there is no change of position or inconsistency in Hohfeld's table of "opposites", as is argued at some length by Professor Kocourek in The Hohfeld System (1920) I5 ILL. L. Rev. 24, 26 ff. The term privilege means the negation of duty, and duty means the negation of privilege. Hohfeld's "privilege" is not the same as Professor Kocourek's "liberty" ("absence of jural relations"). The "juristic utility" of Hohfeld's table of negatives, which Professor Kocourek was unable to see, lies in its operation as a strait-jacket forcing each term in the table to express an unchangeable concept. What the concepts are that were being thus expressed I have tried to show in the text above. Professor Kocourek's juristic tables, continued in his later articles in this number and in I9 Mrch. L. Rev. 47, indicate a considerable change of position from that expressed in I5 IrL. L. REv. 24. Since he did not observe the strait-jacket and persisted in putting the several terms in Hohfeld's mouth to express a concept that Hohfeld did not have, it is impossible to go through the article in I5 ILI. L. RFv. 24, and answer the detailed objections therein, without filling many pages. There is little profit in showing that "I did not say what he said I said". 
more complex conceptions of variable content. We shall still talk of property and contracts and trusts; but we shall also have at our command the machinery of a more exact analysis when the case requires it.

The chief value of Hohfeld's tables of correlatives and negatives is to afford us a quick means of definition and to compel a uniform usage. Hohfeld might have chosen different terms to express one or more of his concepts; but the concepts themselves are clear enough, and his two tables enable us to isolate and identify them with certainty. It has seemed to me that both judicial and popular usage are in almost complete agreement on the meaning of two of these terms: Duty and Power. Working from each of these as a starting point, and proceeding by the aid of correlatives and negatives, we can arrive definitely and quickly at the concepts described by Hohfeld's other six terms.

Nothing will demonstrate the truth of the foregoing except continuous application in concrete cases. To the writer it has been very helpful at every turn; in constructing the law of offer and acceptance, in analyzing the assignment of a contract, in defining a franchise, in determining whether or not a seat on the stock exchange is property. It would weary the reader for me to make many of these applications; but let us consider one simple case.

$A$ gives $B$ his note of hand and $B$ lends money in return. At the due date society commands $\mathrm{A}$ to pay $\mathrm{B}$, and threatens certain consequences in case of non-payment. These consequences are not at all certain to follow, but they are threatened and impending. There is a societal constraint. The giant will act against $A$ and for $B$. Observe that the whole sequence of events is physical. The lending of the money, the note and its delivery, and the threatened consequences of judgment by a court and seizure and sale by a sheriff. These consequences are just as truly physical as the personal act of the creditor would be in demanding payment and grabbing the money out of A's purse. We speak of the law and of legal relations in this case merely because the physical consequences involve some conduct on the part of the agents of society and because there are rules expressing a degree of uniformity in their action, enabling us to predict with some confidence what that action will be.

In order to express the fact that these physical consequences are impending if $A$ does not pay $B$, we say that $B$ has a right to payment, and that $\mathrm{A}$ has a duty to pay. - It is evident that by right and duty we mean that because of certain facts (loan of money and delivery of note) certain physical consequences in the form of action by the agents of the state will take place, if the existing rules leading us to expect such action have not played us false.

Next, suppose that $B$ cancels the note and surrenders it to $A$. We know that this terminates A's duty and B's right, that society is no longer commanding $A$ or threatening him with physical consequences. 
The court will not give judgment and the sheriff will not seize and sell, unless the existing rules have again played us false. How shall we express this fact that the physical consequences above mentioned are no longer impending? Hohfield said: A has a legal privilege not to pay. $\mathrm{B}$ has no longer any right to payment, has no-right.

In chronological sequence, the facts and some of their legal consequences are as follows: (I) A made an offer, creating a power in B and a liability in A-a power and a liability, because B's voluntary act of acceptance is a fact which, in connection with other facts, will stimulate action by state agents towards $A$, and without which such other facts would not stimulate such action. (2) B accepts by lending the money, thus creating a right in himself and a duty in A-a right and a duty, because the agents of society will act physically against A for B's benefit. $B$ has a power also, inasmuch as he can now, by the voluntary act of surrender or cancellation, influence society not to act against A. (3) $B$ cancelled the note, thus extinguishing A's duty and his own right and substituting a privilege in A not to pay.

Let us compare two of these actual situations: first, that existing just after the loan was made; and second, that existing after cancellation. Now it is obvious that in the first case, physical action by state agents against $\mathrm{A}$ is impending and in the second case it is not. This is a vast difference. But in both cases we have rules of uniformity by which we can predict the conduct of the agents of society with respect to $A$ and $B$. These rules we daily teach as rules of law and the courts daily express and apply as rules of law. In the first case the rule is: The delivery of a note for money lent creates a debt and after the arrival of the due date will cause the court to adjudge for $B$ and the sheriff to execute. In the second case the rule is: The cancellation of the note will discharge the debt and will cause the court not to adjudge for $B$ and the sheriff not to execute. Each rule helps us to determine, with more or less certainty, what will be the future physical conduct of the state agents. That knowledge is more specific in the first case than in the second. In the first, we predict affirmative and positive action, although we cannot predict the exact words that the court will use or the exact goods that the sheriff will seize. In the second, we predict forbearance, non-action in a certain respect; we do not try to predict just what the court and sheriff will do affirmatively except that their positive action will be something other than a judgment for $B$ and a seizure of A's goods. That is as specific a prediction as the interests of the parties require. No rule for determining societal action, more specific in character, is necessary, even though it would be competent to our legislative authority to create one.

Shall we say that in the first case $A$ and $B$ are in a legal (or jural) relation and that in the second case they are not? We may if we please, for each of us has the privilege of constructing his own definitions. $\mathrm{He}$ 
who constructs a definition has the rest of the world at a disadvantage. This definition is his fixed and immutable starting point, his universal major premise. Tested by it, the conclusions of all others must be erroneous. Ex vi termini they are wrong. But whatever our definition, it remains true that in each of the two cases we are considering physical facts and are predicting more or less certainly, and more or less specifically, the physical conduct of the appointed agents of the

\footnotetext{
In a very helpful article on Rights in Rem (I920) 68 PA. L. Rev. 322, Professor Kocourek constructs a definition of right in rem as "one of which the essential investitive facts do not serve directly to identify the person who owes the incident duty." Hohfeld had suggested that "A multital right, or claim, (right in rem) is always one of a large class of fundamentally similar yet separate rights, actual and potential, residing in a single person (or single group of persons) but availing respectively against persons constituting a very large and indefinite class of people." Fundamental Legal Conceptions (1917) 26 YALE LAw Journal, 710, 718. A reading of Hohfeld's article shows that he did not represent this to be a fully worked-out and final definition, and in a footnote he expressly reserved one matter for treatment in later articles. The present writer would especially object to the parenthesis "(or single group of persons)" as describing the possible subject (or "dominus") of a single right in rem. Professor Kocourek criticised the definition as "insufficient," and supposed the case where "A, a land owner, has granted an easement to every person in the state [and out of the state, too] to walk across his land except to B." A's right that B shall not enter has now become a "unital" right, although formerly it was one of many, "multital." He adds, "Yet, there can be no doubt that this right is only a right in rent." But there is doubt, because it depends solely upon one's chosen definition. If "multital"-ness is the definitional attribute of right in rem, then this right against $\mathrm{B}$, having lost this attribute, has become in personam.

Professor Kocourek's definition seems to possess the very same weakness that he asserts against Hohfeld's definition; i. e., we can find at least one case where it does not work. Suppose that the investitive facts are such that we know that the duties correlative to A's rights in rem are absolutely umiversal. Are not the persons bearing the duties directly identified by these investitive facts? In Professor Kocourek's case of an infant born alive, with his "general right of corporal integrity," it is conceivable that there is not a single person who does not owe the correlative duty. The duty bearers are just as directly identified by the investitive facts as in Professor Kocourek's case, illustrating rights in personam, of "a contract with the B Co., an unincorporated association, consisting of a thousand members." Would Professor Kocourek assert that the infant's right is not in rem?

The fact is that there is no substantial difference between a right in rem in $A$ against $B$ and $a$ right in personam in $A$ against $B$. The investitive facts creating the two kinds of rights may be identical (e. g., an executed sale of goods on credit), the societal force is always the same, and the physical acts that state agents will do by way of enforcement are the same. The collateral facts of "multital"-ness and absence of identification of the duty-bearers are both interesting, and very likely each has some practical juristic significance (e.g., on 'burden of proof'). Whether or not we should adopt either one as a definitional attribute is a mere question of convenience. But having made a choice, our definition is not invalidated merely because there can be found one or more cases falling within some other definition but not within ours.
} 
community. If it is customary usage to say that in the second case the parties are in a new legal relation, it would seem desirable to follow the custom.

Two more brief illustrations similar to the second case, where Hohfeld used the terms privilege and no-right: Suppose that $A$ asks $B$ concerning the character of B's former servant, C, now applying for a position with $A$. B is under no duty to answer at all, but he has the privilege of answering, and, if he answers without malice and in a truthful spirit, we predict that "the law" will do nothing to him even though his statement is untrue and injurious to C. A legal privilege has replaced his former duty not to make the false statement.

Suppose again that in a friendly bout A gives to B "leave and license" to knock A's hat off. B tries hard, cuffs A often in the attempt, but fails. $A$ is too good a man and his resistance is too strong. Here no wrong is done. $B$ had the legal privilege of cuffing and $A$ the legal privilege of resisting. The social giant would neither help $B$ to get the hat off nor help A to keep it on. Within the limits of reasonable violence there is no societal command to either party. But before the leave and license B's cuffs would have been assault and battery. B's privilege has superseded his former duty not to assault and is not accompanied by a right that A shall not obstruct. Our custom is to say that B's act has become "lawful." Is not this the law? Shall we so far depart from usage as to say that B's act is law-less ?5

Of course, in the vast sum total of combinations of fact, there may be many more in which the state agents will not act than in which they will. If so, it is immaterial. Many combinations of fact never arise for the adjudication of a court or for the opinion of a law instructor. Some of them are taken care of by the unconscious folkways; and no rule of law, no rule indicating uniformity of action by societal agents, has ever been expressed. Until such a rule can be constructed, we do not talk of legal rights and duties or of legal privileges. ${ }^{6}$

\footnotetext{
'See Hohfeld, Fundamental Legal Conceptions (1913) 23 Yale Law Journal, 16, 27, note 59. Professor Kocourek in The Hohfeld System (1920) I5 ILL. L. REv. 24, 35, n. 28, puts the following cases: (I) The privilege of X, the owner of land, to enter on his land. (2) The privilege of a householder to eject a trespasser. (3) The privilege of uttering a libel. (4) The privilege against self-crimination. (5) The privilege of entering on the land of another by license. He assumes that in these cases the term "privilege," as used by Hohfeld, confused "liberty, privilege, and power." In fact, in each case the term privilege expressed merely the fact that society would not penalize the party for his act (or failure to act, as in the fourth example). This is certainly a "juristic fact" of importance and is the same in each case. As to whether or not it is also a "jural relation," consult the text above. In each case, the rule to be applied indicates a uniformity of societal action and is a rule of law. It seems to be Professor Kocourek's idea that in certain cases where society will not penalize a person for his act, this fact is a mere "juristic fact" and not a jural reiation.

"This is why the law does not "break down with its own weight." See I5
} 
In his recent articles, referred to at the beginning, Professor Kocourek has taken Hohfeld's classification and these eight terms, and, while adopting them in greater or less degree, has criticised and has re-defined. With his differences in detail this paper will not undertake to deal. Even though we adhere rigidly to Hohfeld, a considerable part of Professor Kocourek's work will be sound and applicable. But a certain difference in his chosen definition of the term "jural relation" greatly complicates his analysis and multiplies his terms. He has eight "nexal" relations and eight more "simple" or "quasi-jural" relations and eight more "naked" relations. I must leave the explanation of this analysis to Professor Kocourek's own printed articles."

ILI. L. Rev. 36. The "law" does not "supervise every possible act of liberty." A state agent seldom "supervises" any such act. The law has indeed become so complex and detailed as to be beyond the mastery of one man. The courts daily consider new facts and construct new rules for determining whether society will or will not act. But Professor Kocourek cannot get rid of the rules that certain facts will not move society to action merely by affirming that privilege and no-right are mere negations. They are also affirmations that society will not penalize the holder of the privilege when he acts in the privileged way. So also are duty and right negations, for they negative the existence of privilege and no-right. They are also affirmations that society will penalize the holder of the duty when he acts in the un-privileged way. Each concept can be put in either a positive or a negative form (privilege $=$ no duty; duty $=$ no privilege), but the concept expressed remains identical.

It seems quite incorrect to say, as does Professor Kocourek in his article supra, p. 216, that one who sues to obtain a declaratory judgment is merely a "denier" of some jural relation. One who denies the existence of one jural relation between two persons always also asserts the existence of the negative relation; he denies that the existing facts operate to cause one sort of societal action and he asserts that they operate to cause another sort. Even aside from this, he may be asking for a declaration of one or more of the jural relations that Professor Kocourek regards as "positive" and not negative. He may assert a right in himself and a duty in the defendant, and ask for a mere declaration thereof without any judgment on which a writ of execution might issue and without any mandatory order to the defendant.

"If the text above establishes that Professor Kocourek's definition of jural relation, is not the one commonly understood and accepted, and if another definition affords greater simplicity of analysis and equal clearness of expression, it becomes quite unprofitable to follow Professor Kocourek in his complex analysis based upon his conclusions in detail. A re-study of Hohfeld's explanation and illustrations would be of advantage, but a re-statement of them here is not necessary for those who are willing to give the concentrated effort required to master the problem. See Fundamental Legal Conceptions as Applied in Judicial Reasoning (IgI3) 23 YALE LAW JoURNAL, I6; (IgI7) 26 id. 710; Legal Analysis and Terminology (r9I9) 29 YALE LAW JoURNAL, 163.

That Professor Kocourek's "simple" or "quasi-jural relations" are artificial and of little utility is indicated by the fact that a person may be under a "simple duty" to pay money at the same time that he has a "simple privilege" not to pay it. "Thus if $X$ has a claim against $Y$ which is barred by the statute of limitations, $X$ has a claim against $Y$ to an act of performance, but $Y$ has a simple privilege to decline performance. .. . Since claim and privilege are jural negatives, it is evident that in jural relations (strict sense) such a conflict 
He admits the complexity of his result and the difficulty of making some of the distinctions that he thinks necessary to make. ${ }^{8}$ In order to promote accuracy, he would perhaps have invented twenty-four entirely new terms to describe his twenty-four relations, except for the fact that, to quote his own words, "invention here encounters the great, if not insuperable, difficulty of overcoming an inveterate usage which has appropriated a single series of terms for every variety of legal and non-legal situation, and it seems best, therefore, to compromise with it."

Hohfeld effected this compromise at a convenient and serviceable point. He followed "inveterate usage" closely enough to be understood by the average lawyer. He accepted the fundamental concepts "as used in judicial reasoning." The community and the lawyers and the courts persist in describing certain situations of fact as legal (or jural) situations, and they describe as a rule of law any expressed rule for determining the action of societal agents. Hohfeld yielded to their unreasonable practice. All that was necessary was for him to see jural relations with their eyes, and to identify the several fundamental varieties of factual situations and to describe them in ordinary human words. He did not overlook the obvious distinction between cases where societal constraint exists and cases where it does not. The existence of such constraint in the form of impending and predictable action by state agents is one of the most important facts with which we deal. But the

could never exist." I9 Mich. L. Rev. 57. A "simple" contradictory that does not contradict and a "quasi-jural" negative that does not negate has no place in legal terminology. The jural situation is readily described by saying that after the statutory bar $\mathrm{Y}$ is under no legal duty (he has the privilege of not paying), but that the facts are still operative to give to $\mathrm{Y}$ the power of creating a legal duty by new promissory words. There is no sufficient reason for defining the term "power" so as to exclude the case where the new legal relations to be created are disadvantageous. A power is always both constitutive and abrogative according to Hohfeld's classification of legal relations, for it always changes societal action from what it would have been to what it now will be.

${ }^{3}$ As one possible method of avoiding this difficulty and complexity of terminology, Professor Kocourek suggests that we might "ignore any distinction between jural (nexal) and non-jural relations." This he thinks was Hohfeld's method; and he heartily disapproves of it, saying in I9 MrcH. L. REV. 47, 53, note, that it is as unproductive for legal analysis as "the discredited philosophic effort to milk a he-goat through a sieve." But at the worst, this discredited attempt at milking is merely "unproductive," and is far less destructive and wasteful than milking a she-goat through a sieve. Doubtless the thousand milky drops of terminology thus produced would refresh the dry earth with divine nourishment; but whose parched and merely human lips will they reach?

In order to escape the difficulty and complexity of terminology, it is not necessary to "ignore any distinction between jural (nexal) and non-jural relations"; it is merely necessary to ignore Professor Kocourek's distinction between them, and to accept the terms "jural" and "legal" in accordance with inveterate usage.

I9 MICH. L. Rev. 47, 54, note. 
term "legal duty" covers every possible case where this fact exists. ${ }^{10}$ Legal duty means compulsion by society through its executive and judicial agents. It means that to lawyer and to judge and to the man in the street. There might be little harm in defining the term "jural relation" so as to include nothing but rights and duties, in maintaining that no group of facts is "jural" unless constraint by socety is one of them. Privilege, power, and immunity might be called "simple" or "quasi-jural" relations, although the word "simple" makes a weak appeal, and the term "quasi-jural" is worse. But it is harmful to construct a terminology of unnecssary complexity, widely departing from existing usage. It makes both thought and expression more difficult and it cannot be crammed into unwilling mouths.

Hohfeld's eight terms are adequate for the analysis of jural situations of fact. Consider the case of a "right of entry" possessed by A as against $B$. This may connote the following facts: (I) that there is no constraint on $A$ to prevent his entering; (2) that there is constraint on $B$ to prevent him from obstructing A's entry; (3) that after A's entry there will be constraint on third persons as well as on $B$ to prevent them from disturbing $\mathrm{A}$. The term privilege in $A$ (with its correlative no-right in $B$ ) expresses the first of these concepts; $A$ has the privilege of entering. The term right in $A$ (with its correlative duty in $B$ ) expresses the second; $B$ has the duty not to obstruct A's entry. The term power in $A$ (with its correlative liability in $\mathrm{B}$ ) expresses the third; A has the power to regain complete "title" along with possession. These three facts co-exist in this case, but they are not necessarily coexistent in all cases. The fact that there is no constraint on A may exist even though there is also no constraint on $B$; but the fact that $A$ is under no constraint is the same identical fact whether the constraint of $B$ accompanies it or not. Where they do co-exist, we do not need to confuse them into a single concept and to invent a new term like "nexal privilege" to describe it.

${ }^{10}$ The predictable societal action may be "impending" only at a future date, or only after some additional fact, the occurrence of which is uncertain. In the latter case, the customary term is conditional duty. Frequently several operative facts must occur in order to create a presently enforceable duty. We need a term to express the fact that several of these operative facts have already occurred and that the perfect jural relation awaits the occurrence of one or more other facts. The term "conditional" serves this purpose, the awaited facts being described as conditions precedent.

Any of the jural relations may be thus conditional. A pozer may be dependent upon a condition, in which case there is no actual power until the event occurs (although we may speak of a "conditional power"); or the power may be actual and unconditional, but the jural reiations that its possessor can create may themselves be conditional on a future event. See Hanbury v. Bateman [1920] I Ch. 313, in which B had a power to charge certain estates with a payment in case they should come into possession of B's wife by the death of C. B executed a deed before C's death, and it was held operative. 
Consider also a voidable contract. $\mathrm{X}$ promises to deliver a Roman chariot to an infant, who promises in return to pay $\$ 10,000$ one month after delivery. The acts of offer and acceptance are here not void. They are legally operative facts. They create a legal duty in $X$ to deliver; but the infant has the legal privilege of not paying. The infant has a power of disaffirmance at once, a power to terminate his own right to delivery and the duty of $\mathrm{X}$ to deliver. On becoming $2 \mathrm{I}$, and in the absence of a disaffirmance, he will have a power of ratification, a power to substitute a duty of paying in place of his privilege not to pay, and a disability to disaffirm in place of his power of disaffirmance.

Differences in definition of the term "jural relation" may be caused by like differences as to the nature of law and its function. Must a rule of law always be a societal command backed by force? It is perilous to try to state the juristic ideas of another man, it is so easy to misunderstand and to mis-state. But one who thinks that there can be no rule of law and no jural relation between men without societal constraint seems to insist that law does nothing but command. There is no doubt that the command element is of the utmost importance; and according to Hohfeld's classification this element is the factor that defines rights and duties. But it seems to some of us that society not only commands, but also permits and enables and disables. The rules that determine these permissions and enablings and disablings are rules that law schools have to teach, that lawyers have to use in advising clients, and that courts have to create and apply in rendering judgments. And this is true whether there is any societal command or constraint then existing or not. It is difficult to see any element of societal constraint in the concept of permission or of enabling or of disabling. Of course the act permitted may be one of physical constraint against another person; and an enabling act of a legislature may enable certain persons to cause societal constraint. Of course, also, the element of constraint may co-exist with the element of permission or the element of enabling. This is merely to say that society may not be constraining A for B's benefit at the very same time that it is constraining $B$ for A's benefit. But these two facts remain independent facts even though they coexist in time. Constraint is not a part of the permission (the privilege) of $\mathrm{A}$; and permission is not an element in the constraint (the legal duty) of $B$.

In all our discussions of legal analysis, in all our attempts at defining terms or at coining them, we should never cease to bear in mind and give warning that mere legal analysis does not by itself enable us to tell what the law is in a single case. The ability to recognize and to define rights and duties, powers and privileges, and the other relations, does not tell us whether or not they exist in a given case or what facts operate to create them. Rules of law are not constructed by mere analysis and mere logic. As a basis for such construction the judges 
may appeal to "natural justice" or some similar abstraction, to public policy, to "eternal" justice, to the "right" as opposed to wrong, to the settled convictions of the community, to business and social custom, to the mores of the time. ${ }^{11}$ Of course, people do not agree in their notions of right and justice. They do not agree on the policies that make for general welfare and for individual survival. The interests of nations and of individuals are often necessarily in conflict. We can therefore expect war and litigation; and in many important fields the living law will continue to be inconsistent and uncertain. The jurist must therefore be educated in legal history, in anthropology, in economics and social science. But although it is among these that "justice" is to be found, and not in mere logical analysis, it remains equally true that in our search for justice we need desperately to be equipped with the keenest and the truest analytical weapons. Terminology and analysis are the tools that we must use in the process of applying the precedents and in stating rules and policies. They are vitally important tools. They clear the ground and lay bare the underlying legal and social problem to be solved. Without them, we may not see this underlying problem at all; and even if we see it, we may, get lost in the inaccuracy and confusion of our own verbosity.

\footnotetext{
${ }^{11}$ In Whitaker v. Lane (I920, Va.) I04 S. E. 252, the court said: "it cannot be that a rule merely established by precedent is infallible. This would stay all progress and forbid all development. If the rule established by precedent is highly technical and finds its origin in reasons which no longer exist, and the courts have from time to time found it necessary to make exceptions thereto to meet the needs and methods of doing business in modern times, it would seem that the courts should adapt their procedure to the age in which we live and cease to follow a precedent for which they have always to apologise and declare that it is highly technical and not justified by either reason or policy."
} 